University of Nebraska - Lincoln

DigitalCommons@University of Nebraska - Lincoln

10-1955

\title{
Fall Distribution of Birds in a Palouse River Canyon
}

Frank B. Golley

Michigan State University

Paul A. Johnsgard

University of Nebraska-Lincoln, pajohnsgard@gmail.com

Follow this and additional works at: https://digitalcommons.unl.edu/johnsgard

Part of the Ornithology Commons

Golley, Frank B. and Johnsgard, Paul A., "Fall Distribution of Birds in a Palouse River Canyon" (1955). Paul Johnsgard Collection. 14.

https://digitalcommons.unl.edu/johnsgard/14

This Article is brought to you for free and open access by the Papers in the Biological Sciences at DigitalCommons@University of Nebraska - Lincoln. It has been accepted for inclusion in Paul Johnsgard Collection by an authorized administrator of DigitalCommons@University of Nebraska - Lincoln. 


\section{NOTES AND COMMENT}

\section{FALL DISTRIBUTION OF BIRDS IN A PALOUSE RIVER CANYON}

During the fall and winter of 1953 the writers undertook a general ecological study of a portion of the Palouse River valley, near Armstrong, Whitman County, Washington. I) records were kept on the numbers of birds observed and the vegetation in which they were located. It was anticipated that these observations might indicate bird-use of the major vegetational types found in the area.

Several investigators (Dumas 1950; Wing 1949) have published distributional data for birds of the Palouse grassland during the nesting period, but few have been concerned with distribution patterns during the fall migration.

The writers wish to thank Dr. George J. Wallace for critically reading the manuscript.

\section{L.ochtion AND VEgetation}

The area of study was located about one mile north of Armstrong, and included a representative section of the river canyon. This area measured approximately one-half by one mile, parallel to the river, and included the river bottom and the adjoining slopes. A variation of ahout 100 feet vertical distance was found between the river and the top of the canyon slope.

According to Daubenmire's classification (1942) the study area lay within the Festuca-Agropyron zone. However, local conditions were apparently drier than average, with the result that the area showed the aspect of the Agropyron-Poa zone, which is typical of conditions farther west. The Agropyron-Poa association was found on the upper slopes on both siles of the river canyon. Most of this vegetation exhibited extreme disturbance from overgrazing. The Agropyron-Poa association was bounded on the upper side of the valley slope by wheat and pea fields and on the lower side by thickets of Cratacgus douglasii.

Cratacgus occurred in erosion gullies on the canyon slopes and also was an important representative of the floodplain forest found on the valley floor. Other dominant trees of the floodplain forest included Betula microphylla, l'opulus tremuloides, Populus trichocarpa, and Salix spp. Cratacgus and Betula commonly formed dense stands which almost completely excluded herbaceous undergrowth. In one large area Populus tremuloides was dominant over Cratacgus, and excluded other woody species completely, with the exception of a few tall cottonwoods, Populus trichocarpa.

A moist meadow dominated by Elymus cinereus occurred on a level part of the valley floor. In the Elymus community Rumex spp., Sisymbrium altissimum, Arctium minus, Dipsacus syliestris, and Heraclcum lanatum were present. A few woody shrubs, mainly Symphoricarpos albus and Rosa spp., also occurred here.

Minor vegetational areas included a small marshy depression near the river. The very moist conditions allowed a dense growth of Phalaria arundinacea around the borders of the water. Carex spp. and Poa spp. made up the rest of the marsh vegetation. Other portions of the valley floor were cleared for pasture and wheat fields.

The importance of each vegetational type in the study area is shown in the following tabulation:

\author{
Vegetational Typc \\ Floodplain forest \\ Agropyron-Poa \\ Elymus \\ Annual Weeds \\ Other \\ Total
}

Per Cont
40
36
3
1
20
100

\section{Methods}

Trips to the study area were made at weekly intervals from September 26 to December 19, 1953. Observations were made approximately an hour after sunrise. Routes included both in a longitudinal and transverse transect of the river canyon. One observational transect ran along both sides of the Palouse River and included plowed fields, the floodplain forest, the Elymus community, patches of annual weeds, and the small marsh. The second transect ran principally through the AgropyronPoa association, and the floodplain forest. Notes were taken on all birds seen within the study area, recording the vegetational type or plant species each bird or group of birds was utilizing.

\section{Results ANo Discussion}

The relative value of each vegetational type to birds is presented in Table I. Occurrence indicates that a bird or group of birds was observed feeding, perching, or hiding in or under that particular vegetation. "Other" refers to plowed fields, pasture, or uncommon habitat not included in the table.

Since the floodplain forest covered almost one-half of the study area, it was expected that this regetational type would be most important to birds. Birds observed here

TABLE I. Occurrence of single birds or groups of birds in major vegetational types

\begin{tabular}{|c|c|c|c|c|c|}
\hline \multirow[b]{2}{*}{ Species } & \multicolumn{5}{|c|}{ Major Vegetational Type } \\
\hline & 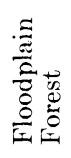 & 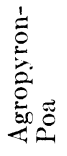 & $\underset{己}{0}$ & 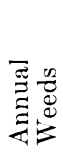 & $\frac{\dot{\theta}}{\dot{0}}$ \\
\hline California quail........ & 8 & & 1 & 3 & \\
\hline Ring-necked pheasant. & 14 & 4 & 4 & 5 & 3 \\
\hline W. mourning dove..... & 2 & . & . & $\cdots$ & . \\
\hline Red-shafted flicker. . . . & 12 & $\ldots$ & . & . & . \\
\hline American magpie..... & 9 & . & & & \\
\hline Black-capped chickadee. & 27 & & . & 3 & 1 \\
\hline American robin ........ & 22 & 2 & & & 1 \\
\hline Ruby-crowned kinglet. . & 4 & . & . & 1 & \\
\hline Cedar waxwing. . . . . . . & 7 & . & . & 3 & 1 \\
\hline Western meadowlark. . . & . & 3 & . & $\cdots$ & . \\
\hline Evening grosbeak..... & 2 & . & . & . & . \\
\hline Common redpoll.... & 1 & . & & . & . \\
\hline Pale goldfish...... & 1 & . & 2 & . & . \\
\hline Spotted towhee. & 1 & & & & \\
\hline Oregon junco ......... & 20 & 1 & 1 & 4 & 5 \\
\hline White-crowned sparrow. & 3 & . & & 3 & . \\
\hline Song sparrow .......... & 12 & . & 1 & 1 & . \\
\hline Total.... & 145 & 10 & 9 & 23 & 11 \\
\hline
\end{tabular}


TABLE II. Occurrence of single birds or groups of birds in the floodplain forest

\begin{tabular}{|c|c|c|c|c|}
\hline Species & 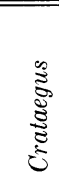 & 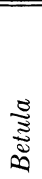 & 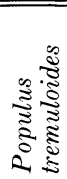 & 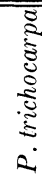 \\
\hline California quail . . . . . . . . . & 8 & $\ldots$ & & . \\
\hline Ring-necked pheasant........ & 12 & 1 & 1 & . \\
\hline W. mourning dove.......... & 2 & . & $\cdots$ & . \\
\hline Red-shafted flicker . . . . . . . . . & 8 & . & . & 4 \\
\hline American magpie.......... & 8 & 1 & . & \\
\hline Black-capped chickadee . . . . . . & 24 & . & & 3 \\
\hline Western robin . . . . . . . . . . & 13 & . & 1. & 8 \\
\hline Ruby-crowned kinglet......... & 4 & . & & \\
\hline Cedar waxwing $\ldots \ldots \ldots \ldots$ & 5 & . & 1 & 1 \\
\hline Evening grosbeak.......... & 1 & . & 1 & $\ldots$ \\
\hline Common redpoll . . . . . . . . . & $\ldots$ & 1 & $\ldots$ & $\ldots$ \\
\hline Pale goldfinch ............ & 1 & $\cdots$ & $\cdots$ & $\cdots$ \\
\hline Spotted towhee........... & 1 & $\therefore$ & . & . \\
\hline Oregon junco ........... & 20 & . & $\cdots$ & . \\
\hline White-crowned sparrow . . . . . . & 3 & . & & . \\
\hline Song sparrow $\ldots \ldots \ldots \ldots \ldots$ & 11 & . & 1 & . \\
\hline Total..... & 121 & 3 & 5 & 16 \\
\hline
\end{tabular}

were also generally thicket-dwelling species. Occurrence of birds in the dominant tree species of the floodplain forest is presented in Table II. It will be seen immediately that Crataegus was by far the most important part of the native vegetation for birds during the period of study. This was probably the result of the profuse fruit it produces as well as the excellent protection which its dense and thorny branches provide. Although cottonwood was a relatively rare tree on the area, it was used to a fairly large extent, particularly by robins and cedar waxwings which seemed to prefer the open view and height which it provided. Although the proportion of birch was nearly one-half that of Crataegus, it was almost completely ignored by birds.

Certain species, such as the western meadowlark, were restricted to one or two vegetational types. Other species, such as the Oregon junco, were seen almost everywhere. Despite this variation, it is evident that Crataegus assumed a position of importance which far exceeded its percentage composition of the total vegetation.

\section{REFERENCES}

Daubenmire, R. N. 1942. An ecological study of the vegetation of southeastern Washington and adjacent Idaho. Ecol. Monog., 12: 53-79.

Dumas, P. C. 1950. Habitat distribution of breeding birds in southeastern Washington. Condor, 52: 232237.

Wing, L. 1949. Breeding birds of virgin Palouse prairie. Auk, $66: 37-40$.

Frank B. Golley

Paul A. Joh NSGard

Department of Zoology,

Michigan State College,

East Lansing, Michigan

Department of Zoology,

The State College of Washington, Pullman, Washington 